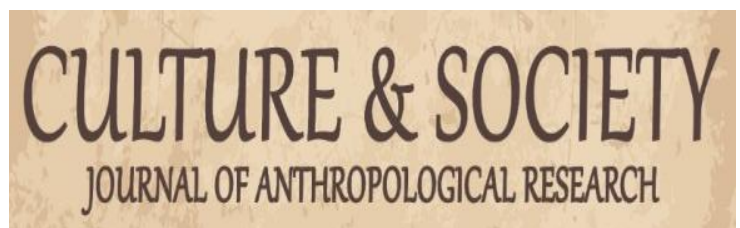

Culture \& Society: Journal of Anthropological Research

VOL. 1 NO. 1 SEPTEMBER 2019

http://culture.ppj.unp.ac.id

Email: culture@ppj.unp.ac.id

ISSN: 2686-343X (E-ISSN) 2686-3421 (P-ISSN)

DOI: https://doi.org/10.24036/culture/vol1-iss1/14

\title{
Konflik dalam Kelompok Tani Gadih Basanai di Kenagarian IV Koto Hilir Kecamatan Batang Kapas, Kabupaten Pesisir Selatan
}

\author{
Citra Maiwulandari ${ }^{1}$, Nora Susilawati ${ }^{2}$ \\ ${ }^{1,2}$ Universitas Negeri Padang \\ Email: citramaiwulandari06@gmail.com, susilawati@gmail.com
}

\begin{abstract}
Abstrak
Penelitian ini dilatarbelakangi karena isu korupsi yang dilakukan oleh pengurus kelompok tani gadih basanai. Penelitian ini akan dianalisis dengan menggunakan Teori Konflik oleh Lewis Coser. Pendekatan yang digunakan dalam penelitian ini adalah pendekatan kualitatif dan pemilihan informan dengan teknik purposive sampling atau penarikan sampel secara sengaja agar mendapatkan data yang lebih akurat. Data pada penelitian ini dikumpulkan dengan cara observasi, wawancara, studi dokumentasi kemudian dianalisis menggunakan teknik analisis data dari Miles dan Huberman. Berdasarkan penelitian hasilnya menunjukkan bahwa bentuk-bentuk konflik yang terjadi di Kelompok Tani Gadih Basanai di isukan adanya korupsi yang menyebabkan terjadinya kekacauan dalam management keuangan, sistem kepengurusan berantakan dan perselisihan sesama pengurus kelompok tani, pengurus dengan anggota dan sesama anggota. Upaya atau solusi dari konflik yang terjadi dalam kelompok tani gadih basanai yaitu merevitalisasi kelompok tani dan menentukan anggaran-anggaran dalam kelompok tani sehingga lebih jelas management keuangan, sistem kepengurusan serta diresmikan oleh pemerintah nagari IV Koto Hilir. Kata Kunci: Konflik, Kelompok tani, penyuluh
\end{abstract}

Abstract
This research is motivated by the issue of corruption carried out by the gadih basanai farmer group management. This research will be analyzed using Conflict Theory by Lewis Coser. The approach used in this study is a qualitative approach and the selection of informants with purposive sampling techniques or deliberate sampling in order to obtain more accurate data. The data in this study were collected by means of observation, interviews, study documentation and then analyzed using data analysis techniques from Miles and Huberman. Based on the research the results showed that the forms of conflict that occurred in the Gadih Basanai Farmer Group were rumored to have caused corruption in financial management, messy management systems and disputes among peasant group management, administrators with members and fellow members. Efforts or solutions to the conflicts that occur in the gadih basanai farmer groups are revitalizing farmer groups and determining budgets in farmer groups so that financial management, management systems and formalized by the nagari IV government of Koto Hilir are clearer.

Keywords: Conflict, Farmer groups, extension workers

\begin{tabular}{|l|l|l|} 
Received: August 29, 2019 & Revised: September 4, 2019 & Published: September 6, 2019 \\
\hline
\end{tabular}


Citra Maiwulandari, Nora Susilawati Konflik dalam Kelompok Tani Gadih Basanai di Kenagarian IV Koto Hilir Kecamatan Batang Kapas Kabupaten Pesisir Selatan

\section{Pendahuluan}

Pertanian merupakan mata pencaharian masyarakat Indonesia. Pada umumnya, kebutuhan yang paling mendasar dikehidupan manusia adalah kebutuhan dalam memenuhi pagan dan kebutuhan tersebut petanilah yang menghasilkan pangan. Petani berbagai macam dalam menanam tanaman, seperti petani menanam padi, petani menanam sayuran dan petani menanam buah-buahan. Pertanian memegang peranan penting dalam ketahanan pangan Indonesia, namun lahan pertanian banyak tidak berfungsi sesuai dengan fungsinya. Pertumbuhan pertanian semaksimal mungkin mendapatkan dukungan dari pemerintah, namun pemerintah kurang maksimal mendukung sehingga semakin tidak baik kondisi pertanian. Hal ini jelas menurut data dari Menteri Pertanian Suswono, bahwa 100 ribu hektar lahan pertanian pertahun beralih fungsi. (No Title, n.d.-a)

Menurut peraturan menteri pertanian nomor:273/Kpts/OT.160/4/2007 Tentang pedoman pembinaan kelembagaan petani, menyatakan bahwa kelompok tani adalah kumpulan petani/peternak/pekebunan yang dibentuk atas dasar kesamaan kepentingan, kesamaan kondisi lingkungan (sosial, ekonomi, sumberdaya) dan keakraban untuk meningkatkan dan mengembangkan usaha anggota. Kelompok tani juga dapat diartikan sebagai organisasi informal di pedesaan yang ditumbuhkembangkan "dari, oleh dan untuk petani" (Peraturan Menteri Pertanian, 2007).

Umumnya kelompok tani dibentuk atas dasar kesamaan kepentingan dan kesamaan kondisi dalam suatu lingkungan petani. Dengan dibentuknya kelompok tani mempermudah untuk menyampaikan materi penyuluhan berupa pembinaan dalam memberdayakan petani agar memiliki kemandirian, bisa menerapkan inovasi, dan mampu menganalisa usaha tani, sehingga petani dan keluarganya bisa memperoleh pendapatan dan kesejahteraan yang meningkat dan layak (Yani \& Farida, 2017).

Penyuluhan pertanian merupakan kegiatan penting dan strategis yang tidak terpisahkan dari pembangunan di sektor pertanian. Kegiatan penyuluhan dalam pembangunan pertanian berperan sebagai jembatan yang menghubungkan antara praktek yang dijalankan oleh petani dengan pengetahuan dan teknologi pertanian yang selalu berkembang (Dalam \& Petani, 2008).

Pada zaman sekarang pengetahuan dan teknologi sangat dimaksimalkan untuk perkembangan pertanian. Namun, keinginan petani dalam mencari informasi mengenai pertanian sangat lemah. Peningkatan layanan informasi juga butuh dukungan semaksimal dari pemerintah, sehingga petani di tuntut untuk lebih kreatif dan inovatif dalam mengembangkan usaha tani (Beberapa, Di, \& Andriaty, 2012).

Adanya kelompok tani bertujuan untuk memperkuat kerjasama antar petani atau nelayan didalam lingkungan organisasi kelompok tani ataupun pihak lain luar kelompok tani. Dengan kerjasama yang dibentuk diharapkan kelompok tani bisa lebih efisien serta lebih mampu menghadapi tantangan, hambatan, gangguan ataupun ancaman dalam usaha tani. Bisa juga bertujuan sebagai wadah belajarnya para petani guna meningkatkan pengetahuan, keterampilan dan sikap baik itu pengurus ataupun anggotanya. Kelompok tani juga merupakan wadah belajar nonformal atau organisasi yang membantu masyarakat petani dalam mengembangkan usaha tani melalui kelompok tani yang telah dibentuk. Terbentuknya kelompok tani juga dipertanggung jawabkan oleh pemerintah nagari dan pihak pertanian daerah (Kerjasama, 1997).

Kelompok tani sangat membantu dalam membangun kerjasama dan membentuk identitas kelompok sebagai petani yang kreatif dan inovasi. Namun, pada penelitian ini peneliti membahas konflik yang terjadi pada kelompok tani gadih basanai di Kenagarian IV Koto Hilir Kecamatan BatangKapas, Kabupaten Pesisir Selatan. Berdasarkan hasil penelitian yang dilakukan oleh peneliti bahwa konflik mula terjadi dikelompok tani gadih basanai (KTGB) yaitu isu korupsi yang dilakukan oleh pengurus kelompok tani. Isu korupsi yang terjadi berubah menjadi korupsi yang dilakukan oleh pengurus kelompok tani pertama dan hal tersebut berlanjut pada pengurus kelompok tani kedua yaitu Bendahara dari KTGB. Berawal korupsi yang terjadi

Culture \& Society: Journal of Anthropological Research Vol. 1, No. 1, Th. 2019 
Citra Maiwulandari, Nora Susilawati Konflik dalam Kelompok Tani Gadih Basanai di Kenagarian IV Koto Hilir Kecamatan Batang Kapas Kabupaten Pesisir Selatan pada KTGB, hubungan sosial sesama pengurus, anggota kelompok tani tidak baik. Mulai muncul pembicaraan yang tidak baik, hal tersebut berkelanjutan sampai sekarang sehingga kelompok tani tidak berkembang, tidak mendapatkan informasi atau pengarahan dari pihak pertanian. Konflik yang terjadi berdampak tidak baik bagi kelompok dan individu, sehingga upaya dari pihak pertanian untuk mengembangkan kelompok tani yaitu merevitalisasi kelompom tani dan anggaran-anggaran dipenuhi atau dibentuk dengan jelas.

\section{Metodelogi Penelitian}

Penelitian ini menggunakan pendekatan kualitatif bersifat deskriptif. Pendekatan kualitatif adalah sebagai prosedur penelitian yang menghasilkan data deskriptif berupa kata-kata tertulis atau lisan dari orang-orang dan perilaku yang dapat diamati. Pendekatan ini diarahkan pada latar dari individu tersebut secara holistik (utuh), dengan penelitian kualitatif ini akan didapatkan informasi berupa ungkapan dan penuturan langsung dari anggota dan pengurus yang terlibat dalam konflik. Menurut Novrianti Makawekes (2016), pendekatan kualitatif yang dimaksud peneliti disini merupakan suatu bentuk penelitian yang mendeskripsikan peristiwa atau kejadian, perilaku orang atau suatu keadaan pada tempat tertentu secara rinci dan mendalam dalam bentuk narasi. Data kualitatif yang diperoleh disini merupakan keseluruhan bahan, keterangan data fakta-fakta yang tidak dapat diukur dengan bentuk angka dan berbentuk tulisan narasi sesaui dengan data yang didapatkan (Kelurahan, Kecamatan, \& Kota, n.d.).

Menurut $(H, 2014)$ penelitian yang menggunakan pendekatan kualitatif ialah suatu proses penelitian ilmiah yang bertujuan untuk memahami masalah-masalah manusia dalam konteks sosial dengan menciptakan gambaran keseluruhan dan kompleks yang disajikan, dilaporkan secara terperinci dari data yang didapatkan atau sumber informasi, serta dilakukan dalam setting yang alamiah tanpa adanya intervensi apapun dari peneliti.

Metode yang digunakan pada penelitian ini ialah studi kasus, dimana pada penelitian ini peneliti ingin mendapatkan beberapa informasi agar paham dengan data yang didapatkan. Ketika mendapatkan data tersebut peneliti menggambarkan dengan jelas berdasarkan dengan dari data lapangan mengenai konflik dalam kelompok tani gadih basanai di Kenagarian IV Koto Hilir, Kecamatan Batangkapas, Kabupaten Pesisir Selatan. Kriteria informan penelitian ini ialah pengurus kelompok tani sebelum dan sesudah mengalami konflik, anggota kelompok tani, wali nagari, PPL Pertanian. Teknik penelitian dalam peneliti ini ialah teknik purposive sampling adalah teknik penelitian yang samplenya bertujuan. Teknik ini digunakan secara sengaja sesuai dengan pertanyaan yang diajukan pada informan kunci, dimana infirman kunci berfungsi untuk menunjukkan siapa saja yang terlibat penyebab terjadinya konflik dalam kelompok tani gadih basanai (Lexy M, 2007).

Untuk mendukung data yang didapatkan, peneliti menggunakan teknik observasi, wawancara mendalam, dan dokumentasi. Observasi yang dilakukan oleh peneliti hanya memantau atau mengamati bagaimana kondisi kelompok tani. Peneliti tidak ikut serta atau mengalami terjadinya kondisi tersebut. Wawancara dilakukan tidak hanya satu hari saja, tetapi wawancara dilakukan pada waktu yang berbeda-beda, hal ini dilakukan agar mendapatkan data yang lebih akurat. Selanjutnya, data dokumentasi yaitu dengan mengambil foto-foto, rekaman suara, catatan observasi dan catatan wawancara mengenai konflik dalam kelompok tani gadih basanai (Spradley, 1997).

\section{Hasil dan pembahasan}

Kelompok tani merupakan kumpulan petani yang terbentuk atas dasar kesamaan kepentingan, keakraban dan keserasian dalam memanfaatkan sumber daya pertanian untuk bekerja sama meningkatkan produktifitas atau perkembangan usaha tani demi kesejahteraan anggotanya sehingga mendapatkan hasil yang layak dalam memenuhi kebutuhan hidup. Namun, dalam pembentukan kelompok tani tentunya kelompok terdiri dari petani-petani

\section{Culture \& Society: Journal of Anthropological Research Vol. 1, No. 1, Th. 2019}


Citra Maiwulandari, Nora Susilawati Konflik dalam Kelompok Tani Gadih Basanai di Kenagarian IV Koto Hilir Kecamatan Batang Kapas Kabupaten Pesisir Selatan sebagai aktor dalam mengembangkan usaha tani. Petani merupakan pengelola usaha tani yang terdiri dari petani peternak, dan perkebunan (Ternak, Perah, \& Wilayah, 2007).

Pembentukan kelompok tani merupakan salah satu bentuk untuk mewujudkan dan mengembangkan usaha tani. Kelompok tani dikatakan sebagai kumpulan petani-petani dewasa, pria dan wanita, tua dan muda, dimana mereka yang terlibat dalam usaha tani. Petani yang telah bergabung dengan kelompok tani bekerjasama dan dibantu oleh PPL Pertanian. Pihak pertanian memberikan informasi melalui penyuluhan yang disampaikan pada KTGB, hal itu rutin sekali 15 hari dilakukan. Namun, KTGB tidak rutin berkumpul untuk memusyawarakan tentang perkembangan kelompok tani (Yogyakarta, Emiria, \& Purwandari, 2014).

Penyuluhan pertanian merupakan kegiatan penting dan strategis yang tidak terpisahkan dari pembangunan di sektor pertanian. Kegiatan penyuluhan dalam pembangunan pertanian berperan sebagai jembatan yang menghubungkan antara praktek yang dijalankan oleh petani dengan pengetahuan dan teknologi pertanian yang selalu berkembang (Ulfa \& Djaja, 2018)

Untuk data kelompok tani di Kenagarian IV Koto Hilir selengkapnya dapat dilihat pada tabel barikut :

Tabel 1. Kelompok Tani di Kenagarian IV Koto Hilir, Kec.Batang Kapas

\begin{tabular}{|c|c|c|c|}
\hline No & Kampung & Nama kelompok tani & $\begin{array}{l}\text { Tahun } \\
\text { berdiri }\end{array}$ \\
\hline 1 & TL. Batuang & Taluak Batuang & 1989 \\
\hline \multirow[t]{5}{*}{2} & Jalamu & Kapalo Banda & 1987 \\
\hline & & Salak & 1989 \\
\hline & & Tunas Saiyo & 1984 \\
\hline & & Kp. Ladang & 2002 \\
\hline & & Tani Sepakat & 2009 \\
\hline \multirow[t]{6}{*}{3} & Pasar Kuok & Pasar Kuok & 1999 \\
\hline & & Sumber Abadi & 2009 \\
\hline & & Gadih Basanai & 2005 \\
\hline & & Tani Maju & 1997 \\
\hline & & Inuang & 1998 \\
\hline & & Sago Indah & 2013 \\
\hline \multirow[t]{3}{*}{4} & Limau Sundai & Limau Sundai 1 & 1979 \\
\hline & & Limau Sundai 2 & 2007 \\
\hline & & Kp.Hilir & 1981 \\
\hline
\end{tabular}

Culture \& Society: Journal of Anthropological Research Vol. 1, No. 1, Th. 2019 
Citra Maiwulandari, Nora Susilawati

Konflik dalam Kelompok Tani Gadih Basanai di Kenagarian IV Koto Hilir Kecamatan Batang Kapas Kabupaten Pesisir Selatan

\begin{tabular}{lc} 
Sabirawang & 2007 \\
\hline Kampung Aur & 2007 \\
\hline Mandiangin & 2011
\end{tabular}

Sumber : Rencana Kerja Tahunan Penyuluh Pertanian (RKTP) 2019 (Nova, 2019)

Berdasarkan pengamatan penulis terhadap konflik yang terjadi dalam kelompok tani di Kenagarian IV Koto Hilir, bahwa konflik telah terjadi di salah satu kelompok tani di Kenagarian tersebut. Kelompok Tani di Kenagarian IV Koto Hilir terdiri dari 18 kelompok tani. kelompok tani tersebut berasal dari 3 kampung yang berbeda tetapi pada Kenagarian yang sama. Kelompok tani yang paling awal dibentuk di Kenagarian itu adalah Kelompok Tani Kp. Hilir yang berasal dari kampung Limau Sundai yang berdiri pada tahun 1981, dan sejak tahun 1981 sampai tahun 2013 terbentuklah kelompok tani yang lain seperti yang terlihat pada tabel diatas.

Wawancara dilakukan dengan Ibu Yenti Nova (penyuluh pertanian) tentang permasalahan kelompok tani yang menyatakan bahwa dari ke_18 kelompok tani yang ada di Kenagarian tersebut hampir semua kelompok tani mengalami konflik atau pertentangan antara pengurus dengan anggotanya serta sesama anggota. Pada umumnya konflik bisa terjadi karena beberapa hal salah satunya yaitu ketidaksesuaian pendapat, dan perselisihan yang membuat kondisi dalam kelompok tidak baik. pertentangan tersebut dapat diselesaikan dan menemukan titik akhirnya yaitu dengan cara dipertemukan semua anggota kelompok dengan pengurus kelompok, dan salah satu pendamping pertanian, membahas permasalahan apa yang telah terjadi sehingga membuat kelompok tidak produktif lagi, permasalahan dalam kelompok terselesaikan.

Berbeda dengan kelompok tani Gadih Basanai (KTGB). Dimana, mengalami konflik yang pada saat ini tidak pernah terselesaikan. KTGB mengalami masalah yang diawali karena ketua pegurus dan anggota kelompok tidak semua menghadiri rapat dengan penyuluhan pertanian. Disamping itu, mulai muncul pembicaraan yang tidak baik diantara sesama anggota kelompok tentang pengurus kelompok tani, begitu juga dengan kepengurusan dalam kelompok tani mulai tidak baik, hal tersebut sering terjadi lambat laun menimbulkan konflik sosial.

Berdasarkan penelitian yang dilakukan oleh peneliti bahwa di Kenagarian IV Koto Hilir telah berdiri kelompok tani sejak tahun 2005 yaitu kelompok tani gadih basanai yang dimana terjadi konflik sampai sekarang tidak terselesaikan. Konflik terjadi di mulai munculnya pembicaraan yang tidak baik karena KTGB di isukan korupsi oleh pengurus kelompok tani tersebut. Permasalahan tersebut menimbulkan beberapa dampak terhadap kelompok tani itu sendiri.

Hal ini menyebabkan kesalahan dalam managemen keuangan dan sistem kepengurusan kelompok. Interaksi yang terjadi sesama pengurus yaitu ketua dan bendahara tidak baik, begitu juga dengan anggota sudah tidak ada kerjasama lagi, mengakibatkan terhalangnya proses perkembangan pertanian pada KTGB, Bahkan konflik meningkat seperti perselisihan dan ketegangan. Ketua pengurus dari kelompok tani sudah tidak bertahan dengan kondisi kelompok yang tidak jelas bagaimana kelanjutannya. Disaat itu, ketua berusaha mencari solusi yang pada akhirnya mengundurkan diri.

Namun, tidak satu pun dari pengurus dan anggota kelompok yang mau mengambil kedudukan tersebut. Salah satu dari pengurus kelompok mencarikan calon lain yang akan melanjutkan kelompok tani agar tetap berkembang. Tetapi, anggota kelompok tidak menyetujui pergantian ketua kelompok, sehingga sampai sekarang KTGB masih di ketuai oleh Bapak Basril, kelompok tidak berkembang dengan baik dan konflik tersebut berkelanjutan sampai sekarang ini. Disamping itu kelompok tani gadih basanai juga dikategorikan sebagai kelompok tani yang berprestasi dimana KTGB berhasil menggunakan bibit baru dari pemerintah melalui PPL Pertanian. Namun, KTGB juga merupakan kelompok tani yang buruk dimana sistem

\section{Culture \& Society: Journal of Anthropological Research Vol. 1, No. 1, Th. 2019}


Citra Maiwulandari, Nora Susilawati Konflik dalam Kelompok Tani Gadih Basanai di Kenagarian IV Koto Hilir Kecamatan Batang Kapas Kabupaten Pesisir Selatan kepengurusan tidak baik, management keuangan tidak jelas, bahkan menimbulkan perselisihan dan ketegangan sesama pengurus, sehingga sampai sekarang kelompok tani tidak aktif atau tidak ada perkembangannya. Berdasarkan wawancara yang dilakukan oleh peneliti bahwa upayah dalam penyelesaian konflik tersebut yaitu merevitalisasi kelompok tani dan menentukan anggaran-anggaran dengan jelas serta diketahui oleh pemerintah nagari dan pihak pertanian.

Kelompok Tani Gadih Basanai dikategorikan sebagai kelompok tani yang berprestasi, namun kelompok tani ini termasuk pada kelompok tani yang jauh tertinggal, tidak ada perkembangannya dikarenakan konflik yang terjadi sampai sekarang tidak terselesaikan. Penyebab terjadinya konflik tersebut karena hal korupsi yang telah dilakukan oleh pengurus dalam KTGB. Awal mula terjadinya karena korupsi ketika itu anggota dalam kelompok tani mengalami kekacauan, seperti sistem kepengurusan tidak jelas. Sistem kepengurusan pada KTGB hanya tertumpu pada ketua saja. Pada dasarnya kelompok tani merupakan organisasi informal sebagai wadah dalam mengembangkan usaha tani. Dalam organisasi atau kelompok tani memiliki struktur organisasi seperti ketua, sekretaris, bendahara, dan anggota (Sjahruddin, Gani, Kepemimpinan, Kerja, \& Kerja, 2017).

Kelompok Tani Gadih Basanai sistem kepengurusan mengalami kekacauan, hal ini terjadi karena fungsi dan peran dalam kelompok tani tidak berjalan sesuai dengan fungsinya. Pada dasarnya suatu kelompok sosial dalam mengembangkan kelompok harus sesuai menjalankan fungsi dan peran masing-masing pengurus, agar perkembangan kelompok berjalan dengan baik.

Konflik yang terjadi dalam Kelompok Tani Gadih Basanai dapat diselesaikan dengan musyawarah yaitu revitalisasi kelompok tani kembali dan diketahui oleh pemerintah nagari. Permasalahan dalam kelompok tani dapat diselesaikan dengan upaya yang diberikan demi mendapatkan kembali identitas kelompok (No Title, n.d.-b).

\section{Kesimpulan}

Berdasarkan hasil penelitian yang telah dilakukan oleh peneliti mengenai Konflik dalam Kelompok Tani Gadih Basanai di Kenagarian IV Koto Hilir, Kecamatan Batangkapas, Kabupaten Pesisir Selatan, terdapat beberapa upaya-upaya yang dilakukan untuk konflik yang terjadi pada Kelompok Tani Gadih Basanai setelah melakukan beberapa wawancara dengan Pihak pertanian, anggota yang terlibat konflik dan yang tidak terlibat dalam konflik yaitu revitalisasi kelompok tani, hal ini dilakukan demi keadilan dan kesejahteraan kelompok tani, agar kelompok tani dapat berkembang dan anggota dalam kelompok dapat mengembangkan usaha tani sendiri. Selanjutnya, setelah terbentuknya kelompok tani baru, kelompok tani harus menetukan anggaran-anggaran yang jelas, sehingga tidak terjadi kekacauan dalam kelompok tani.

\section{Daftar Pustaka}

Beberapa, D. I., Di, K., \& Andriaty, E. (2012). Ketersediaan Sumber Informasi Teknologi Pertanian Availability of Agricultural Technology Information Source at Several Districts in Java. 21(1), 3035.

Dalam, P., \& Petani, M. (2008). Urnal enyuluhan. 4(2).

H, H. (2014). metode penelitian kualitatif untuk ilmu-ilmu sosial. Jakarta: Salemba Humanika.

Kelurahan, D. I., Kecamatan, M., \& Kota, B. (n.d.). 1, 2 , 2 1. 1-14.

Kerjasama, M. (1997). Pengembangan Dinamika Kelompok Tani melalui Kerjasama Hanok Untajana *). $8-17$.

Lexy M. (2007). metode penelitian kualitatif. Bandung: Remaja Rosdakarya.

No Title. (n.d.-a). 131-150.

No Title. (n.d.-b). 1-20.

Nova, Y. (2019). Rencana Kerja Tahunan Pertanian (RKTP), Batang Kapas, Pesisir Selatan.

\section{Culture \& Society: Journal of Anthropological Research Vol. 1, No. 1, Th. 2019}


Citra Maiwulandari, Nora Susilawati Konflik dalam Kelompok Tani Gadih Basanai di Kenagarian IV Koto Hilir Kecamatan Batang Kapas Kabupaten Pesisir Selatan

Sjahruddin, H., Gani, M., Kepemimpinan, G., Kerja, S., \& Kerja, K. (2017). Jurnal organisasi dan manajemen. 2(2), 62-77.

Spradley, J. (1997). metode penelitian etnografi.

Ternak, K., Perah, S., \& Wilayah, D. (2007). Kepemimpinan Ketua Kelompok Dan Hubungannya Dengan Keefektifan Kelompok (Kasus Pada Kelompoktani Ternak Sapi Perah Di Wilayah Kerja ( The Leadership of Chairman Groups And Its Association With Groups Effectiveness (In Cases of Dairy Farmers Groups of KSU Tandangsari Area )). 7(2), 179-185.

Ulfa, E. A., \& Djaja, S. (2018). Harjomulyo Kecamatan Silo Kabupaten Jember Kopi. 12, 116-121. https://doi.org/10.19184/jpe.v12i1.7619

Yani, D. E., \& Farida, I. (2017). Dinamika kelompok sentra penyuluhan kehutanan dan pedesaan mangga delima taman nasional karimun jawa. 10(3), 58-67.

Yogyakarta, D. I., Emiria, F., \& Purwandari, H. (2014). The Development of Organic Farming in Tani Madya Groups of Kebonagung Village, District. 10(2). 